\title{
ZEFERINO VAZ
}

\author{
Ruy Ferreira-Santos
}

Professor Catedrático Emérito do Departamento de Cirurgia, Ortopedia e Traumatologia da Faculdade de Medicina de Ribeirão Preto da Universidade de São Paulo.

\section{VOCATIVOS}

Escolheram-me por ser um dos derradeiros remanescentes da primeira hora. Esta é a quarta vez em que esta Faculdade de Medicina de Ribeirão Preto me escolhe e designa seu intérprete para falar, em nome dela, sobre Zeferino Vaz. As outras foram:

- quando, constituída a primeira congregação, em 1964, Zeferino, seu fundador e primeiro diretor, dela se despediu, ao fim de doze anos de muito empenho e trabalho dedicado. Naquele vinte de março, nas minhas palavras, esta escola o saudou, reconhecida, e lhe fez bons augúrios;

- depois, foi quando redigi seu necrológio, em fevereiro de 1981;

- e, por fim, no dia catorze de maio daquele mesmo ano, durante a sessão solene em que a congregação reverenciou sua memória, presente a família Vaz.

Trata-se, hoje, de assinalar o significado dos desvelamentos inaugurais desta herma e da placa frontal na fachada do edifício mestre.

O significado é simples e direto:

"É certo conferir ao merecedor o que de justiça lhe cabe".

Nas origens da instituição e entre os criadores que a fundaram, destaca-se Zeferino Vaz por muitos títulos:

- membro da comissão da Universidade a selecionar a sede geográfica de uma segunda faculdade de medicina da USP;
- presidente da comissão encarregada do planejamento e da instalação;

- parlamentário da Universidade junto ao Governo Municipal e às forças vivas da Comunidade Ribeirãopretana;

- diretor designado e empossado;

- seletor atilado de cérebros capazes, nacionais e estrangeiros, para constituírem o corpo docente inicial;

- priorizador das ações produtivas bem equipadas, antes de edificações, a estas cabendo ser simplesmente adequadas e não ostentatórias;

- pólo atrativo do respeito, da admiração e da amizade de figuras como Antonio Rodrigues, Lourenço Roselino, Waldemar Pessoa, Paulo Romeu, Luiz Augusto Gomes de Mattos, Osmany Emboaba, Amin Calil, Thomaz Whately, Divo Marino e os grandes jornalistas da época, Porto, Sant'Ana, Virdes, Cortez, Romano e Camargo;

- negociador hábil, que, logo cedo, conquistou para a Escola de Medicina este magnífico "campus", as portas abertas da Santa Casa e do Hospital São Francisco e, já no quarto ano de sua existência, o próprio hospital-escola.

- inovador revolucionário no ensino médico, de currículo modelo, com ênfase na prática clínica, na integração programática interdisciplinar, vertical e horizontal, na organização departamental, no tempo integral (quer o rígido, quer o geográfico) e na inclusão da Psicologia Médica e da Bioestatística no esquema curricular;

Discurso proferido em 7 de março de 1997 por ocasião da inauguração do busto de Zeferino Vaz e nominação do Prédio Central da Faculdade de Medicina de Ribeirão Preto da Universidade de São Paulo. 
- incentivador incansável do espírito de pesquisa, fazendo da Faculdade um centro de excelência, a ponto de ela logo se ter tornado merecedora do auxílio, dos subsídios e de bolsas concedidas pela Fundação Rockefeller, e, por esta, apontada, junto com a Faculdade de Medicina de Cali (Colômbia), como um dos focos-exemplo na América Latina;

- instigador da produção científica original, tanto de pesquisa pura, experimental ou clínica, como da aplicada, esta em torno, especialmente, da Nosologia regional e brasileira;

- impulsionador de carreiras e da titulação gradual e crescente, que, aos poucos, efetivadas, resultaram ter, afinal, a faculdade a sua própria congregação e considerar-se Zeferino com a missão cumprida.

Retirou-se, em 1964, e logo alçou grandes vôos realizadores, em São Paulo, em Brasília e em Campinas. Discursou, ao afastar-se proferindo os melhores votos pela continuidade da sua obra amorável e, experiente e vivido como então era, recomendou-nos, a nós, seus sucessores:

“... cuidado com a burocracia enrijecida, com o corporativismo interesseiro e com a mediocridade míope, pois esterilizam as instituições..."

Felizmente sua obra encontrou ilustres continuadores dedicados, que lhe mantiveram a grandeza e lhe acresceram mais fama e prestígio.

A Faculdade de Medicina de Ribeirão Preto deve muito, muitíssimo, a Zeferino Vaz, sonhador e executivo, capaz de pairar junto a nuvens altas, mas sem perder o rumo nem as amarras ao solo firme. Grande dívida, quase imensa!

Em boa parte ela se resgata agora, neste momento. O diretor cessante, Prof.Dr. José Antunes Rodrigues, pela iniciativa recente, e os colegiados atuais merecem nisso todo apoio e muito aplauso.

Eu penso até que tardou demais este reconhecimento público e ostensivo. Transcorreu um período em que a imagem e o mérito de Zeferino ficaram como que envoltos em névoa de esquecimento. Sua família deu-se conta. Preferiu, até, confiar a Campinas e não a nós preciosos arquivos dele, onde se resguardam importantes documentos históricos desta casa.

Em 1977, quando do jubileu de prata da nossa faculdade, propus à congregação que, entre outras celebrações pertinentes, se erigisse o busto do fundador. Assim. Aqui mesmo. Não passou. Cunhou-se apenas um medalhão-efígie, desde então incrustado na alvenaria do segundo andar, tímido, quase incógnito, pouco lembrado.

As novas gerações de alunos de graduação ou de pós-graduação, até mesmo de docentes e pesquisadores, não foram, durante algum tempo, estimuladas a cultuar a memória e a tradição. A tal ponto que, faz uns seis anos, a uma aluna do terceiro ano, que, com um grupo de colegas do Centro Acadêmico, tentava ressuscitar o jornalzinho "Esteto", e obter depoimentos dos antigos, eu perguntei:

- "Você sabe quem foi Zeferino Vaz, não sabe?"

E ela me respondeu:

_ "Claro! O fundador da UNICAMP".

Felizmente isso passou. A amnésia curou-se.

Falei talvez demais. É que, ileso da desmemória, aqui dei o testemunho justificativo que espero lhes traduza, aos que me ouviram e aos que me lerem, um grande amor por esta minha segunda faculdade. Faço agora uma sugestão-pergunta: não caberia imitar o exemplo da minha primeira faculdade, a de Pinheiros, minha alma-mater, a "Casa de Arnaldo"? Lá, todos os anos, dia cinco de junho, aniversário do falecimento de seu criador, Arnaldo Vieira de Carvalho, há uma homenagem comemorativa junto a seu busto, fronteiro à porta nobre. Aí falam o docente de mais recente ingresso e um representante dos alunos.

Seria aqui algo semelhante, anualmente, dia catorze de maio, natalício de Zeferino Vaz, Memória Reavivada.

Neste busto, dedicadamente esculpido por Quita Carrion, Zeferino contempla, realizado como os artesãos de antigamente, um dos frutos da sua vida. $\mathrm{E}$ contempla, desde agora, a "Casa de Zeferino". 